\title{
Akreditation No:36/E/KPT/2019

\section{BIOSYNTHESIS AND CHARACTERIZATION OF GOLD NANOPARTICLES AND THEIR INTERACTION STUDY WITH METFORMIN}

\author{
Dian Anggraini ${ }^{1}$, Siti Suhartati ${ }^{1}$, Iwan Syahjoko Saputra ${ }^{1}$ and Sudirman ${ }^{2}$ \\ ${ }^{1}$ Academy of Analytical Chemistry Caraka Nusantara \\ Jl. Tugu Raya Komplek Timah, Depok 16951 \\ ${ }^{2}$ Center for Science and Technology of Advanced Materials - BATAN \\ Kawasan Puspitek, Serpong 15314, Tanggerang Selatan \\ E-mail:iwan_chemistry@yahoo.co.id
}

\begin{abstract}
BIOSYNTHESIS AND CHARACTERIZATION OF GOLD NANOPARTICLES AND THEIR INTERACTION STUDY WITH METFORMIN. Synthesis of gold nanoparticles successfully carried using Imperata cylindrica $L$ leaf extract. In this study, the approach used through green synthesis method is a reaction betwen of the $\mathrm{HAuCl}_{4}$ solution (concentration variation as 3;5;7 x 10-4 M) with Imperata cylindrica $\mathrm{L}$ leaf extract. Results of UV-Vis showed of gold nanoparticles has a maximum wavelength at $530 \mathrm{~nm}$ with absorbance value of 1.4. Results of FTIR shows a shift the absorption peak at wavenumber of $3392 \mathrm{~cm}^{-1}$ to $3404 \mathrm{~cm}^{-1}$. PSA and PZC showed the distribution of gold nanoparticles was $48.84 \mathrm{~nm}$ with a charge of $20.5 \mathrm{mV}$. Gold nanoparticles has a spherical shape and an average particle size of $20 \mathrm{~nm}$ which can be seen from the results of the characterization using TEM. XRD showed crystalize size average of gold nanoparticles as $20.47 \mathrm{~nm}$. The interaction between of gold nanoparticles with metformin can be seen in the absorbance decrease of 0.38 at a wavelength of $531 \mathrm{~nm}$ and the results of PSA shows an average particle size of AuNPs@metformin is $122 \mathrm{~nm}$. From the characterization data can be concluded the gold nanoparticles were successfully synthesized using natural bioreductors by utilizing secondary metabolites from Imperata cylindrica L leaf extract.
\end{abstract}

Keywords: Biosynthesis, Gold Nanoparticles, Imperata cylindrica L, Metformin

\begin{abstract}
ABSTRAK
BIOSINTESIS DAN KARAKTERISASI NANOPARTIKEL EMAS DAN STUDI INTERAKSI DENGAN METFORMIN. Sintesis nanopartikel emas berhasil dilakukan menggunakan ekstrak daun ilalang (Imperata cylindrica L). Metode yang digunakan pada penelitian ini yaitu pendekatan melalui green synthesis yaitu mereaksikan larutan $\mathrm{HAuCl}_{4}$ (variasi konsentrasi 3; 5; $7 \times 10^{-4} \mathrm{M}$ ) dengan ekstrak daun ilalang. Hasil UV-Vis menunjukkan koloid nanopartikel emas memiliki serapan panjang gelombang maksimum pada $530 \mathrm{~nm}$ dengan nilai absorbansi 1.4. Hasil FTIR menunjukkan adanya pergeseran puncak serapan pada bilangan gelombang $3392 \mathrm{~cm}^{-1}$ menjadi $3404 \mathrm{~cm}^{-1}$. Hal ini mengindikasikan adanya interaksi gugus -OH pada ekstrak daun ilalang terhadap ion $\mathrm{Au}^{3+}$. Hasil PSA dan PZC menunjukkan distribusi ukuran nanopartikel emas sebesar $48.84 \mathrm{~nm}$ dengan muatan sebesar $20.5 \mathrm{mV}$. Nanopartikel emas memiliki bentuk bulat dan rata-rata ukuran partikel $20 \mathrm{~nm}$ yang terlihat dari hasil karakterisasi menggunakan TEM. Hasil XRD memperlihatkan kristal nanopartikel emas dengan rata-rata ukuran kristal sebesar $20.47 \mathrm{~nm}$. Adanya interaksi antara nanopartikel emas dengan metformin terlihat pada penurunan nilai absorbansi nanopartikel emas sebesar 0.38 pada panjang gelombang 531 nm dan hasil PSA menunjukkan ukuran rata-rata partikel AuNPs@metformin sebesar 122 nm. Dari data karakterisasi dapat disimpulkan bahwa nanopartikel emas berhasil disintesis menggunakan bioreduktor alami dengan memanfaatkan metabolit sekunder dari ekstrak daun ilalang.
\end{abstract}

Kata kunci: Biosintesis, Nanopartikel Emas, Imperata cylindrica L, Metformin 


\section{INTRODUCTION}

Gold nanoparticles are one of the metal that are many of still being studied, because has many uniqueness. Gold nanoparticles has particle size shapes from 1-100 $\mathrm{nm}$ and high particle stability. Precursors used in the synthesis of gold nanoparticles typically use tetrachloroauric (III) acid $\left(\mathrm{HAuCl}_{4}\right)$ as a source of $\mathrm{Au}^{3+}$ ions. Visually, the formation of gold nanoparticles is characterized by changes in the color of $\mathrm{HAuCl}_{4}$ solution. In the process of reducing $\mathrm{Au}^{3+}$ ions to $\mathrm{Au}^{0}$ involving reductants such as natrium tetrahidridoborat $\left(\mathrm{NaBH}_{4}\right)$, citric acid and sodium citrate [1]. This reducing agent is very dangerous and not environmentally friendly. Therefore, it is necessary to replace natural reductants through the green synthesis approach. Extracts from leaves, flowers, roots, and fruits on plants can be used as natural reducing agents in the synthesis of gold nanoparticles.

Tinospora crispa leaf extract [2], Pistacia integerrima gall extract [3], Salix alba extract [4], Polyscias fruticosa leaf extract [5], Citrus maxima aqueous extracts [6], cornelian cherry (Cornus mas) fruits extract [7], Nerium oleander leves extract [8], aqueous garlic (Allium sativum L) extract [9], successfully used as a reducing agent in the synthesis of gold nanoparticles. Visually, the color changes occur in colloidal gold nanoparticles such as: purple-blue and ruby-red [3,4], yellow, pink, blue and purple-grey [10], light yellow to violet [11], and yellow to red purple [12]. The difference in color produced in colloidal gold nanoparticles proves varying particle size. Gold nanoparticles has localized surface plasmon resonance (LSPR) properties that can vary according to the shape and size of the particles produced. The shape of the nanosphere, nanoshells and nanorod in particles of gold has different optical properties [13].

Colloid of gold nanoparticles can function as a drug delivery system that can interaction with ubiquicidin (29-41) [14], amoxicillin coated-AuNPs [15], vancomycin capped-AuNPs [16], ampicillin, streptomycin, and kanamycin conjugated-AuNPs [17], cefaclor and aminoglycoside-conjugated AuNPs $[18,19]$. In this study, colloid of gold nanoparticles will be interacted with the metformin drug.

Metformin is a drug used for diabetes mellitus of type 2. Giving the drug metformin will cause side effects if it is not on target. Side effects such as tremors, hypoglycemia, vomiting and nausea [20]. In this research, extraction of leaves of Imperata cylindrica $L$ using water solvent will be carried out. Water fraction of Imperata cylindrica $L$ leaf will be used as a medium and natural reductant agent in the synthesis of gold nanoparticles. Colloid of gold nanoparticles that are formed are expected to be able to interact with metformin drug which are seen on decreasing theabsorbance value on the spectrophotometer UV-Vis.

\section{EXPERIMENTAL METHOD}

\section{Materials and Instruments}

Sample of Imperata cylindrica $L$ leaf were taken from Depok Area (West Java, Indonesia). Metformin was purchased from Merck (Darmstad, Germany). Gold metal 99.9\% from PT Antam ( Jakarta, Indonesia) and $\mathrm{HNO}_{3}$ and $\mathrm{HCl}$ purchased from Sigma-Aldrich (Missouri, United States).

Characterization of gold nanoparticles using Shimadzu UV-Vis Spectrophotometer 2600 (Kyoto, Japan) with wavelength from $200-800 \mathrm{~nm}$ set and equiped with wolfram lamp as a light source. Interactions of functional group are analyzed using Shimadzu Fourier Transform Infrared (FTIR) Prestige 21 Spectroscopy with wavenumbers from $4000-400 \mathrm{~cm}^{-1}$ set and using nernst lamps (Kyoto, Japan). Particle size distribution seen using Particle Size Analyzer (PSA) and Potential Zeta Charge (PZC) Malvern ZEN 1600 with dynamic light scattering system (Malvern, United Kingdom). Morphological shapes of gold nanoparticles were seen using Transmission Electron Microscopy (TEM) JEM 1400, using $350 \mathrm{keV}$ of electron beam energy (Nagoya, Japan). Crystal of gold nanoparticles in analyzed using Shimadzu X-ray Diffraction (XRD) 610 with Cobalt us a source of electron (Kyoto, Japan).

\section{Method and Procedure}

About $5 \mathrm{~g}$ of Imperata cylindrica $L$ leaf was added $50 \mathrm{~mL}$ aquadest and stirred for 4 hours at $60{ }^{\circ} \mathrm{C}$ temperature. The results of Imperata cylindrica $L$ leaf extract, are calculated percent yield and solution stock concentration. $\mathrm{HAuCl}_{4}$ solution was synthesized by dissolving $99.9 \%$ gold metal with aqua regia $\left(\mathrm{HNO}_{3}: \mathrm{HCl}\right)$ solvent with ratio of 1:3.

Synthesis of gold nanoparticles using various concentration of $\mathrm{HAuCl}_{4}\left(3 ; 5 ; 7 \times 10^{-4} \mathrm{M}\right)$ respectively. About $10 \mathrm{~mL} \mathrm{HAuCl}_{4}$ was added $1 \mathrm{~mL}$ Imperata cylndrica $L$ leaf extract $(\mathrm{v} / \mathrm{v})$. The reaction takes place at room temperature for 24 hours. Test of interaction was carried out by reacting $5 \mathrm{~mL}$ colloid of gold nanoparticles $\left(7 \times 10^{-}\right.$ ${ }^{4} \mathrm{M}$ ) with $2 \mathrm{~mL}$ of metformin solution $\left(4 \times 10^{-4} \mathrm{M}\right)$.

\section{RESULT AND DISCUSSION}

The process of extraction of Imperata cylindrica $L$ leaf lasts for four hours and produces a brown solution. After calculation, the results of Imperata cylindrica $L$ leaf extract has a $0.5 \%$ yield and a stock concentration of the solution of $5 \%$. Synthesis of $\mathrm{HAuCl}_{4}$ solution of gold metal $99.9 \%$ produces a yellow color. Figure 1 shows the results of Imperata cylindrica $L$ leaf extract the water fraction and the $\mathrm{HAuCl}_{4}$ solution. $\mathrm{HAuCl}_{4}$ discoloration is seen after the addition of Imperata cylindrica $L$ leaf extract. The colloid of gold nanoparticles with various 


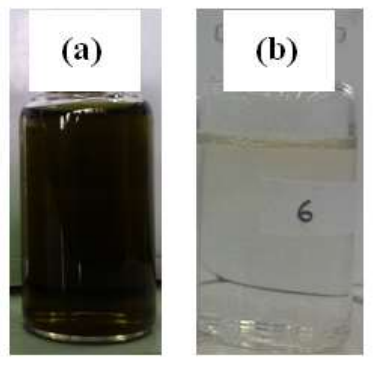

Figure 1. (a). Imperata cylindrica L Leaf Extract and (b). $\mathrm{HAuCl}_{4}$ Solution

concentrations of $\mathrm{HAuCl}_{4}$ produces a red-purple color. Figure 2 shows the color of the synthesis of gold nanoparticles using Imperata cylindrica $L$ leaf extract.

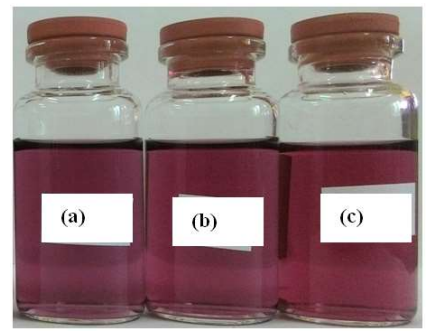

Figure 2. Colloid of Gold Nanoparticles with Various Concentration of $\mathrm{HAuCl}_{4}$ (a). $3 \times 10^{-4} \mathrm{M}$, (b). $5 \times 10^{-4} \mathrm{M}$, and (c). $7 \times 10^{-4} \mathrm{M}^{4}$

The higher the concentration of $\mathrm{HAuCl}_{4}$ used, the colloidal color of gold nanoparticles produced is increasingly red-purple. This indicates that many nanoparticles are formed [21]. The reduction reaction that occurs is seen in equation 1.

$$
\mathrm{Au}^{3+}+\mathrm{e}^{-} \rightarrow \mathrm{Au}^{0}
$$

The source of electrons used to reduce $\mathrm{Au}^{3+}$ ions is predicted to come from phenol groups found in the flavonoid compound of Imperata cylindrica $L$ leaf extract [12]. The colloid of gold nanoparticles has surface plasmon resonance (SPR) properties that can be seen on the UV-Vis spectrum. Figure 3 shows a spectrum of

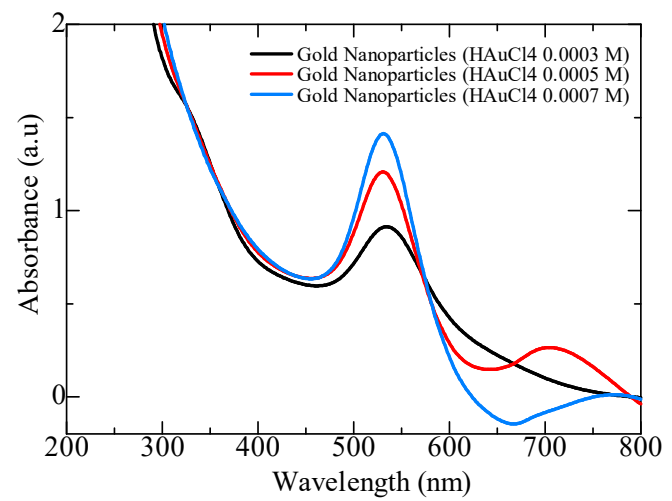

Figure 3. UV-Vis spectrum of gold nanoparticles colloid with various concentration of $\mathrm{HAuCl}_{4}$. gold nanoparticles with various concentrations of $\mathrm{HAuCl}_{4}$ used. The wavelength of $530-532 \mathrm{~nm}$ is used to see the maximum absorption peak $\left(\lambda_{\max }\right)$ of gold nanoparticles formed. Phenomena of surface plasmon resonance on gold nanoparticles occur in visible light (530-532 nm wavelength).

The higher concentration of $\mathrm{HAuCl}_{4}$ used, the greater of absorbance value of gold nanoparticles produced. The higher absorbance value of gold nanoparticles, the better of colloid stability, and the tendency of gold particles to form agglomeration is getting smaller [22]. Data on wavelength and absorbance values of gold nanoparticles are shown in Table 1.

Table 1. Data of Wavelength and Absorbance Values of Gold Nanoparticles with Various Concentration of $\mathrm{HAuCl}_{4}$

\begin{tabular}{ccc}
\hline $\begin{array}{c}\text { Concentration } \\
\mathrm{HAuCl}_{4}\end{array}$ & $\begin{array}{c}\lambda_{\max } \\
\text { Gold Nanoparticles }\end{array}$ & $\begin{array}{c}\text { Absorbance } \\
\text { Value }\end{array}$ \\
\hline $3 \times 10^{-4} \mathrm{M}$ & $532 \mathrm{~nm}$ & 0.9 \\
$5 \times 10^{-4} \mathrm{M}$ & $530 \mathrm{~nm}$ & 1.2 \\
$7 \times 10^{-4} \mathrm{M}$ & $530 \mathrm{~nm}$ & 1.4 \\
\hline
\end{tabular}

Apart from act as a reducing agent, the function group such as $\mathrm{C}-\mathrm{H}, \mathrm{C}-\mathrm{N}, \mathrm{C}=\mathrm{C}$ in Imperata cylindrica $\mathrm{L}$ leaf extract also functions as a capping agent for gold nanoparticles [23]. Figure 4 shows the functional groups found in secondary metabolites on Imperata cylindrica $L$ leaf extract and the spectrum of gold nanoparticle colloids.

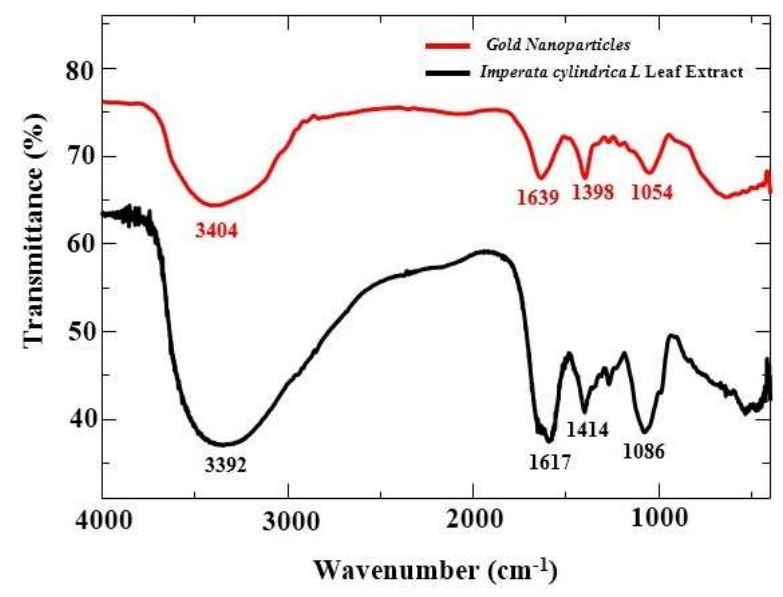

Figure 4. FTIR Spectrum of Imperata cylindrica L leaf Extract and results of biosynthesis of gold nanoparticles.

FTIR analysis functions to determine the functional groups found in Imperata cylindrica $L$ leaf extract. The functional groups in secondary metabolites of Imperata cylindrica $L$ leaf extract act as $\mathrm{Au}^{3+}$ ion reduction agents and capping agents for gold nanoparticles [23]. There is a shift in the absorption peak at the wavenumber from $3392 \mathrm{~cm}^{-1}$ to $3404 \mathrm{~cm}^{-1}(-\mathrm{OH})$, $1617 \mathrm{~cm}^{-1}$ to $1639 \mathrm{~cm}^{-1}(\mathrm{~N}-\mathrm{H}), 1414 \mathrm{~cm}^{-1}$ to $1398 \mathrm{~cm}^{-1}(\mathrm{C}-\mathrm{N})$, and $1086 \mathrm{~cm}^{-1}$ to $1054 \mathrm{~cm}^{-1}(\mathrm{C}=\mathrm{C})$ [24]. This functional group indicates the presence of a compound as such flavonoids, alkaloids, terpenoids, and protein [25]. 
PSA and PZC results show the particle size distribution of gold nanoparticles. The peak of one has a size of $9.7 \mathrm{~nm}$ and a peak of two has a size of $87.98 \mathrm{~nm}$. The average size of gold nanoparticles was $48.84 \mathrm{~nm}$ with a potential zeta charge is $20.5 \mathrm{mV}$. Figure $5 \mathrm{a}$ shows the graph of PSA and PZC of gold nanoparticles (5b).

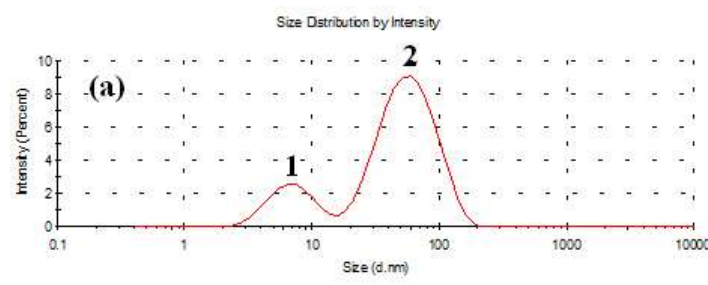

Zeta Puerriá Devilusion

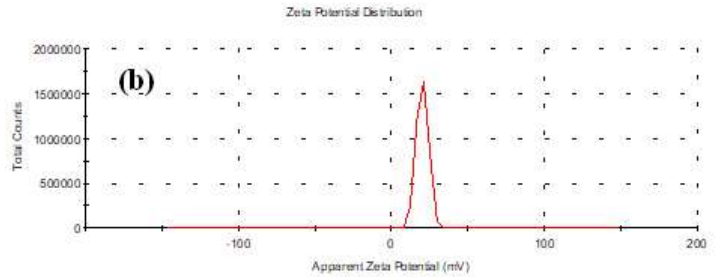

Figure 5. Spectrum Image of Gold Nanoparticles (a). PSA, and (b). PZC.

Results of the monodisperse nature of gold nanoparticles (PDI=0.578) and the value of PZC is corresponding to TEM images, gold nanoparticles have good stability.

Figure 6 showed of TEM images of gold nanoparticles. Gold nanoparticles have spherical shapes with particle size is $20 \mathrm{~nm}$. The results of TEM showed the good homogeneity of gold nanoparticles. The density of gold particles was seen to be higher than the capping agent of Imperata cylindrica $L$ leaf extract which was marked with strong black color on TEM.

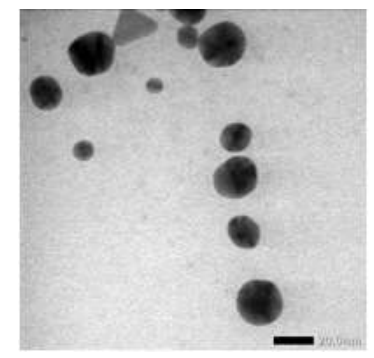

Figure 6. TEM of Gold Nanoparticles

There is a difference in the size of gold nanoparticles from the results of measurement using PSA and TEM. Results of PSA, the size of gold nanoparticles $(87.98 \mathrm{~nm})$ is greater than the results of TEM $(20 \mathrm{~nm})$. The measurement using PSA, there are several functional groups of Imperata cylindrica $L$ leaf extract which acts as a capping agent for colloid of gold nanoparticles to be measured. Characterization using TEM, only shows of gold nanoparticle metals that measured, because the density of gold is greater than the functional groups in the extract.
The crystal structure of gold nanoparticles is analyzed as seen in XRD (fig. 7). Four Bragg reflection peaks are distinctly exhibited at $38.24^{\circ}, 44.49^{\circ}, 64.78^{\circ}$, and $77.85^{\circ}$ were indexed with the planes (111), (200), (220), and (311) of the face-centered cubic (fcc) structure of metallic gold (JCPDS no. 65-2870). These results are in corresponding with previous studies [26]. After the calculated using the Debye-Scherrer's, the average size of gold nanoparticles was obtained is $20.47 \mathrm{~nm}$.

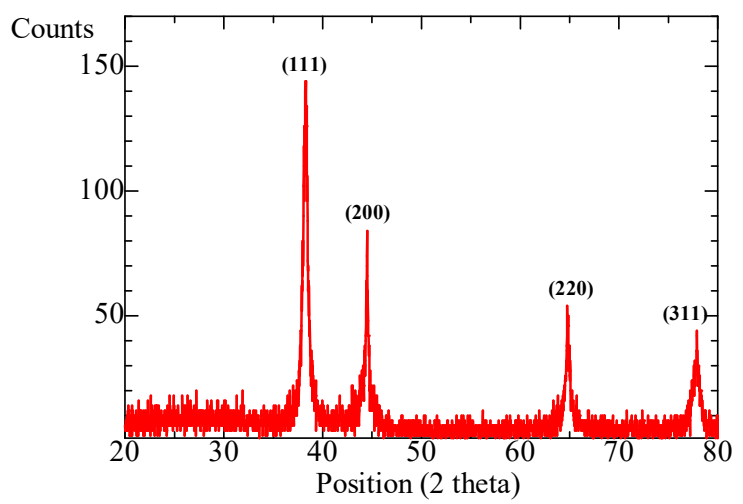

Figure 7. XRD Spectrum of as Biosynthesis Gold Nanoparticles.

Interactions of metformin with gold nanoparticles will increase the particle size of gold nanoparticles. Figure 8 showed a shift in wavelength from $530 \mathrm{~nm}$ (a) to 531 $\mathrm{nm}$ (b). The absorbance value of gold nanoparticles also decreased from 1.4 to 0.38 . The presence of a new peak at wavelength $233 \mathrm{~nm}$ with an absorbance value of 0.54 is a typical peak of the metformin drug [27].

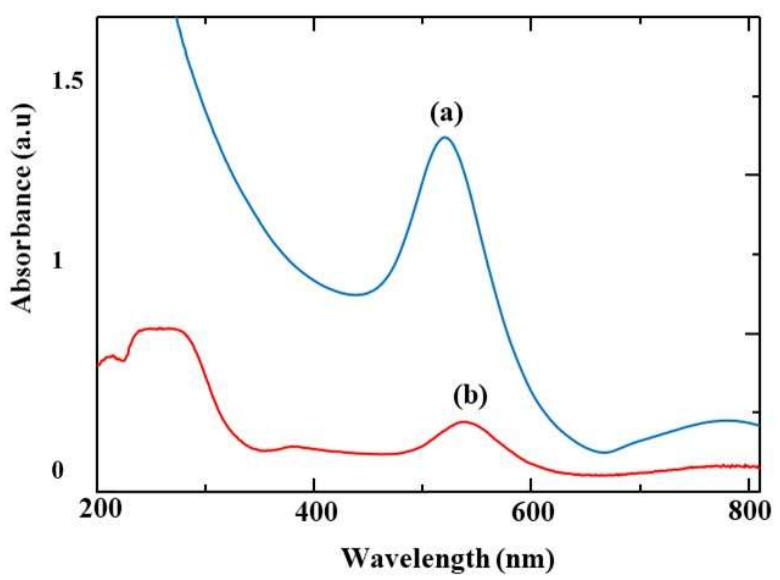

Figure 8. UV-Vis Spectrum of (a). Gold Nanoparticles and (b). Gold Nanoparticles@Metformin.

The interaction of gold nanoparticles with the metformin drug resulted in average particle size of 122 nm (fig. 9). Gold nanoparticles@metformin has a PDI value $=0.588$ with three peaks of different sizes. The presence of active groups contained in metformin such as $-\mathrm{NH}_{2},-\mathrm{CH}_{3}$, and $-\mathrm{NH}$ can interact on the surface of gold nanoparticles, causing the gold particle size to be larger as seen from the PSA analysis [20]. 


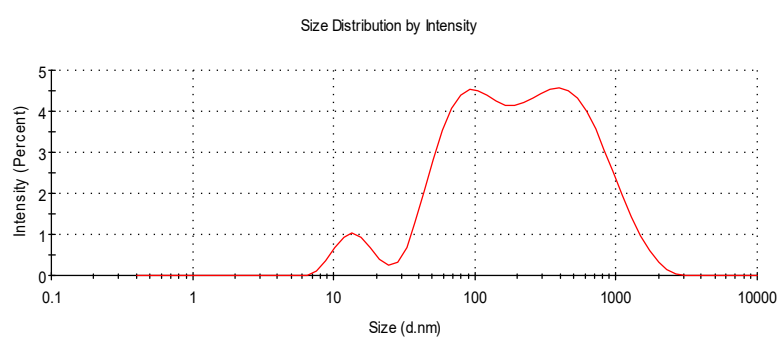

Figure 9. PSA Spectrum Image of Gold Nanoparticles @Metformin

\section{CONCLUSION}

Secondary metabolites contained Imperata cylindrica $L$ leaf extract is very influential on the success of the synthesis of gold nanoparticles. UV-Vis showed the characteristic of gold nano particles with $\mathrm{HAuCl}_{4} 7 \times 10^{-4} \mathrm{M}$ solution has the highest absorbance value of 1.4 with a wavelength of $530 \mathrm{~nm}$. FTIR showed the sharp bands at $3392 \mathrm{~cm}^{-1}$ corresponding to $-\mathrm{OH},-\mathrm{N}-\mathrm{H},-\mathrm{C}-\mathrm{N},-\mathrm{C}=\mathrm{C}-$ functional group for Imperata cylindrica $L$ leaf extract. PSA and PZC values of $48.84 \mathrm{~nm}$ and $20.5 \mathrm{mV}$. The morphology of gold nanoparticles has sphere shapes with particle size is $20 \mathrm{~nm}$. The crystal size of gold nanoparticles is $20.47 \mathrm{~nm}$ with face-centered cubic shapes. The interaction between metformin with gold nanoparticles is seen at wavelength shifts from 530 to $531 \mathrm{~nm}$ and PSA shows an average particle size of $122 \mathrm{~nm}$

\section{ACKNOWLEDGMENT}

Thanks to the ministry of research and technology of higher education through the novice lecturer competitive research grant (PDP) 2019.

\section{REFERENCES}

[1] H. Tyagi, A. Kushwaha, A. Kumar, and M. Aslam, "A Facile pH Controlled Citrate-Based Reduction Method for Gold Nanoparticle Synthesis at Room Temperature," Nanoscale Res. Lett., vol. 11, no. 362, 2016.

[2] D. O. B. Apriandanu and Y. Yulizar, "The role of aqueous leaf extract of Tinospora crispa as reducing and capping agents for synthesis of gold nanoparticles," in IOP Conference Series: Materials Science and Engineering, 2017, vol. 188, p. 12013.

[3] N. U. Islam, K. Jalil, M. Shahid, N. Muhammad, and A. Rauf, "Pistacia integerrima gall extract mediated green synthesis of gold nanoparticles and their biological activities," Arab. J. Chem., vol. 12, no. 8, pp. 2310-2319, 2019.

[4] N. U. Islam et al., "Green synthesis and biological activities of gold nanoparticles functionalized with
Salix alba," Arab. J. Chem., vol. 12, no. 8, pp. 2914 2925, 2019.

[5] Y. Yulizar and Q. Ayun, "Bio-prospective of Polyscias fruticosa leaf extract as redactor and stabilizer of gold nanoparticles formation," in IOP Conference Series: Earth and Environmental Science, 2017, p. 60.

[6] J. Yu, D. Xu, H. N. Guan, C. Wang, L. K. Huang, and D. F. Chi, "Facile one-step green synthesis of gold nanoparticles using Citrus maxima aqueous extracts and its catalytic activity," Mater. Lett., vol. 166, pp. 110-112, 2016.

[7] M. Perde-Schrepler et al., "Gold nanoparticles synthesized with a polyphenols-rich extract from cornelian cherry (Cornus mas) fruits: Effects on human skin cells," J. Nanomater., vol. 2016, 2016.

[8] K. Tahir et al., "Nerium oleander leaves extract mediated synthesis of gold nanoparticles and its antioxidant activity," Mater. Lett., vol. 156, pp. 198201, 2015.

[9] Y. Yulizar, H. A. Ariyanta, and L. Abdurrachman, "Green synthesis of gold nanoparticles using aqueous garlic (Allium sativum L.) extract and its interaction study with melamine," Bull. Chem. React. Eng. \&amp;amp; Catal., vol. 12, no. 2, pp. 212-218, 2017.

[10] C. Zapata-Urzúa et al., "Hantzsch dihydro pyridines: Privileged structures for the formation of well-defined gold nanostars," J. Colloid Interface Sci., vol. 453, pp. 260-269, 2015.

[11] N. K. R. Bogireddy, K. K. Hoskote Anand, and B. K. Mandal, "Gold nanoparticles - Synthesis by Sterculia acuminata extract and its catalytic efficiency in alleviating different organic dyes," J. Mol. Liq., vol. 211, pp. 868-875, 2015.

[12] I. Syahjoko Saputra, Y. Yulizar, and S. Sudirman, "Effect of Concentration of Imperata Cylindrica L Leaf Extract on Synthesis Process of Gold Nanoparticles," J. Sains Mater. Indones., vol. 19, no. 2,pp. 72-76, 2018.

[13] P. K. Jain, K. S. Lee, I. H. El-Sayed, and M. A. El-Sayed, "Calculated absorption and scattering properties of gold nanoparticles of different size, shape, and composition: Applications in biological imaging and biomedicine," J. Phys. Chem. B, vol. 110, no. 14, pp. 7238-7248, 2006.

[14] E. Morales-Avila et al., "Antibacterial Efficacy of Gold and Silver Nanoparticles Functionalized with the Ubiquicidin (29-41) Antimicrobial Peptide," J. Nanomater, vol. 2017, 2017.

[15] M. Demurtas and C. C. Perry, "Facile one-pot synthesis of amoxicillin-coated gold nanoparticles and their antimicrobial activity," Gold Bull., vol. 47, no. 1-2, pp. 103-107, 2014.

[16] H. Gu, P. L. Ho, E. Tong, L. Wang, and B. Xu, "Presenting vancomycin on nanoparticles to 
enhance antimicrobial activities," Nano Lett., vol. 3, no. 9, pp. 1261-1263, 2003.

[17] B. Saha et al., "In vitro structural and functional evaluation of gold nanoparticles conjugated antibiotics," Nanoscale Res. Lett., vol. 2, no. 12, pp. 614-622, 2007.

[18] A. Rai, A. Prabhune, and C. C. Perry, "Antibiotic mediated synthesis of gold nanoparticles with potent antimicrobial activity and their application in antimicrobial coatings," J. Mater. Chem., vol. 20, no. 32, pp. 6789-6798, 2010.

[19] A. Nirmala Grace and K. Pandian, "Antibacterial efficacy of aminoglycosidic antibiotics protected gold nanoparticles-A brief study," Colloids Surfaces A Physicochem. Eng. Asp., vol. 297, no. 1-3,pp. 63-70, 2007.

[20] R. Joddy Sutama Putra, A. Achmad, and H. Rachma Pramestutie, "Kejadian Efek Samping Potensial Terapi Obat Anti Diabetes Pada Pasien Diabetes Melitus Berdasarkan Algoritme Naranjo," Pharm. J. Indones., vol. 2, no. 2, pp. 45-50, 2017.

[21] M. Koperuncholan, "Bioreduction of chloroauric acid ( $\mathrm{HAuCl} 4$ ) for the synthesis of gold nanoparticles (GNPs): A special empathies of pharmacological activity," Int. J. Phytopharm. Res. Artic., vol. 5, no. 4, pp. 72-80, 2015.

[22] F. Chen, Y. Wang, J. Ma, and G. Yang, "A biocompatible synthesis of gold nanoparticles by
Tris(hydroxymethyl)aminomethane," Nanoscale Res. Lett., vol. 9, no. 1, 2014.

[23] H. Fouad et al., "Controlling Aedes albopictus and Culex pipiens pallens using silver nanoparticles synthesized from aqueous extract of Cassia fistula fruit pulp and its mode of action," Artif. Cells, Nanomedicine Biotechnol., vol. 46, no. 3, pp. 558567, 2018.

[24] M. Kaykhaii, N. Haghpazir, and J. Walisadeh, "Biosynthesis of gold nanoparticles using aqueous extract of stem of Periploca aphylla plant," J. Nanostructures, vol. 8, no. 2, pp. 152-158, 2018.

[25] A. Folorunso et al., "Biosynthesis, characterization and antimicrobial activity of gold nanoparticles from leaf extracts of Annona muricata," J. Nanostructure Chem., vol. 9, no. 2, pp. 111-117, 2019.

[26] F. Arockiya Aarthi Rajathi, R. Arumugam, S. Saravanan, and P. Anantharaman, "Phytofabri cation of gold nanoparticles assisted by leaves of Suaeda monoica and its free radical scavenging property," J. Photochem. Photobiol. B Biol., vol. 135, pp. 75-80, 2014.

[27] R. R. Ambadas and R. B. Saudagar, "Estimation of Metformin Hydrochloride by UV Spectro photometric Method in Pharmaceutical Formulation," World J Pharm Sci, vol. 2, no. 12, pp. 1841-1845, 2014. 